\title{
US Trade and Investment in Africa: What Are the Prospects for the $21^{\text {st }}$ Century?
}

\section{N Frank Ekanem}

Department of Finance, International Business \& Insurance, Howard University

\section{ABSTRACT}

African countries considered in this study face many supply constraints and so lack the capacity to produce. Export promotion effort cannot be successful unless such constraints are removed. Transparency in governance, improvements in basic infrastructure and economic liberalization are some of the ways to remove such constraints. Direct private investment to accelerate economic expansion rather than exchange rate manipulations are needed before export promotion policy can be successful.

JEL F02

Prior to the 1980s the US, like many other industrialized countries, invested to develop the largely untapped natural resources in Africa. These countries served as sources of raw materials for the US manufacturing sector. According to the US Department of Commerce, at the year-end of 1995, the US direct investment in Sub-Saharan Africa was $\$ 4,487$ million, $\$ 1,269$ million of which was in South Africa, $\$ 650$ million in Angola and $\$ 595$ million in Nigeria. There was a large outflow of capital from the United States for new investments, or to expand existing investments in South Africa and Nigeria. Most of the US trade with Africa is driven by the US investment interest in that region. This acknowledgement by the Department of Commerce says it all: (1) US direct investment in Africa supports US trade with the region, (2) \$684 million of US merchandise exports in 1994 were shipped to US majority-owned affiliates in Africa, including those in North Africa. The major US export markets in SubSaharan Africa are South Africa and Nigeria.

The United States imports virtually all its manganese, a mineral essential for the production of high grade steel and relies on Gabon for about one-third of its needs. Because of its heavy reliance on Nigeria for its crude oil import, the US invested in oil exploration in that country. These countries together accounted 
for 63 per cent of US exports to the region in 1996. Transportation equipment, agricultural products, machinery, electronic products and chemicals were the largest US merchandise exports in 1996. US imports rose to a record high $\$ 15.1$ billion in 1996. With its investment in the region, the United States was able to obtain one-fifth of its crude oil imports and similarly about 65 per cent of the US vanadium, 44 per cent of antimony, 33 per cent of its platinum group requirement, over 30 per cent of its chromite and its ferro-chrome, 27 per cent of its gold and 10 per cent of its manganese imports from South Africa. Abundant natural resources, pent-up demand for consumer products, capital goods and western technology presented an excellent environment for developing manufacturing and distribution facilities in many African countries.

An increased awareness of Africa as a market for traded goods and services, rather than merely a source of raw materials characterized the beginning of the 1990s. This was further enhanced by significant positive developments in Africa, which created a sense of economic and political renewal throughout the African continent. African countries have also implemented many economic reforms emphasizing growth, private sector development and greater openness to the global economy. This renaissance took place amidst equally dramatic changes in the global political system and significant important opportunities for African nations to deepen their participation in the global economy in numerous and mutually beneficial ways (Rogers, 1998). Now that an increasing number of African countries are becoming strong candidates as potential trade and investment partners, the United States is once again at the forefront of the industrialized world in pursuit of new opportunities. The passage of African Growth and Opportunity Act is just one step intended to secure a positive and rewarding economic relationship between Africa and the United States. Although many Africans and African American leaders have expressed considerable skepticism, the Act contains several provisions which can facilitate African access to American markets and vice versa. In particular, the call to eradicate corruption, improve and strengthen infrastructural services and carry out macro- and microeconomic reforms are some of the ways to attract direct private investment.

As recently as May 1997, a distinguished panel of African scholars, American businessmen and experts called on the Clinton administration to develop a new and activist policy toward the continent to sustain development. In many ways, sustainable development embraces all of the primary objectives of the preceding decades and represents a better and more integrated understanding of Africa's development challenges. The Clinton administration was quite aware that failure to fully appreciate the economic aspects of this continent-wide renewal, would represent a lost opportunity for the United States to utilize a positive 
challenge in ways beneficial to the US, African nations and the larger global economy.

\section{RECENT TRENDS IN THE US TRADE WITH AFRICA}

The US trade with Africa since 1980 consisted mainly of machinery and transport equipment, mineral fuels and lubricants, beverages and tobacco, animal and vegetable oil, chemicals and related products. Between 1989 and 1992, the US export of mineral fuels and lubricants grew at the rate of 6.9 per cent, machinery and transport equipment grew at 11.1 per cent; miscellaneous manufactured articles grew at 14.4 per cent per annum. Most of these exports went to Egypt and Nigeria. US export of miscellaneous manufactured articles to Egypt and to Nigeria during the period grew at an annual rate of 21.2 per cent and 8.3 per cent respectively. From 1989 to 1992, the US export of machinery and transport equipment to Egypt and Nigeria grew annually at 12.5 per cent and 3.3 per cent respectively. These trends were drastically changed between 1993-96. While the US export of mineral fuels and lubricants nearly tripled at 22.3 per cent per annum, exports of manufactured goods nearly doubled at 11.1 per cent per annum. US export of machinery and transport to Africa fell drastically from 11.1 per cent to 1.5 per cent per annum, despite a phenomenal 134 per cent annual growth in these exports to Nigeria. Export of miscellaneous manufactured articles also fell from 14.4 per cent to 7.1 per cent per annum, in spite of 18.9 per cent per annum increase to South Africa, partly because the US export of these products to Nigeria fell by 8.9 per cent per annum and exports to Egypt remained unchanged.

An examination of US imports from Africa reveals a very interesting phenomenon. During the period 1989-1992, the growth rate of US imports was dominated by the imports of animal and vegetable oil. US imports of animal and vegetable oil from Africa was growing at a rate of 70.3 per cent per annum, beverages and tobacco at about 34.2 per cent per annum, chemicals and related products about 19.3 per cent per annum and miscellaneous manufactured articles at approximately 13.6 per cent of the overall US imports from Africa. Also, from 1989 to 1992, US imports from Africa prominently featured machinery and transport equipment, accounting for approximately 31.6 per cent per annum, animal and vegetable oil (about 25.0 per cent per annum) and chemicals and related products (about 14.0 per cent per annum). However, during this period, the US imports of food and live animals, crude materials and manufactured goods fell and generally recorded negative growth rates. Between 1993 and 1996, the growth rate of US imports began to rise. Imports of food and live animals grew at an annual rate of 12.2 per cent. Crude materials, which had been declining at an annual rate of 1.6 per cent during the period of 1989 . 
92, now grew at an annual rate of 7.9 per cent; while the US imports of manufactured goods grew at an annual rate of 4.9 per cent. The growth of US imports from Africa during this period primarily stemmed from imports of miscellaneous manufactured articles from South Africa. This category of imports grew at an annual rate of 55.4 per cent while imports of machinery and transports equipment grew at an annual rate of 32.8 per cent, chemicals and related products at an annual rate of 17.3 per cent and food and live animals at an annual rate of 14.7 per cent.

\section{THE DIRECTION AND COMPOSITION OF US TRADE WITH AFRICA}

The US Department of Commerce acknowledges that US trade and investment in Africa are interdependent. Most US direct investment in Africa has been designed to support US trade in the region and hence the bulk of US merchandise exports was shipped to US majority-owned affiliates in the region. This situation is not dictated by economic theory, but is generally justified and practised by most multinational corporations. Nevertheless, US trade with African countries depends on the structure of the African economies, which structure gives rise to countries' inability to export under given circumstances and also determines countries' capacity to import. The capacity to import depends on the income and prices in the African countries, relative to those in the USA. A standard export model partly explains this phenomenon. The standard model emphasizes two main factors:

(i) a production function that comprises the stock of capital and labor supply and (ii) environmental factors which emphasize labor productivity, capital productivity and shifts of capital from domestic to the export sector (Tyler, 1981; Feder, 1982 and Esfahani, 1991). This model must be modified to reflect the reality of the African situation, to include important environmental factors that will attract direct private investment and accelerate economic growth. Without these modifications, the standard model will be inappropriate. Both the ability to export and the capacity to import arguments are explored in this study.

Based on the Department of Commerce trade data, the fastest growing US exports to Africa consisted of wheat, approximately 17.5 per cent; coal, approximately 12.9 per cent; parts and accessories of motor vehicles, approximately 21.5 per cent; iron and steel tubes, pipes etc, approximately 16.8 per cent; and engineering and motor, non-electrical parts, approximately 11.7 per cent. On the other hand, the fastest growing US imports from Africa consisted of cocoa, approximately 17.4 per cent; pig iron, approximately 17.4 per cent; liquefied propane, approximately 17.5 per cent; sugars, molasses and 
honey, approximately 37.2 per cent; and crude minerals, approximately 29.5 per cent. These are manufactured and agricultural commodities, which the United States and African countries either have the technology or comparative advantage to produce more efficiently. The United States has the technology to produce engineering equipment and motor vehicle and parts, as well as the comparative advantage to produce wheat and many other agricultural products.

African countries, on the other hand, that have exported to the United States in significant amounts either have comparative advantage in agricultural products, such as cocoa or are endowed with large reserves of crude minerals, such as coal and petroleum. In this regard, statistics show that between 1993 and 1996 US imports of mineral fuels, lubricants and related materials came from Angola and Nigeria. During this period, 14.1 per cent and 32.8 per cent of the United States' imports of mineral fuels, lubricants and related materials from Africa came from Angola and Nigeria, respectively. While products, such as civil engineering and contractors' plant and equipment, iron and steel tubes, pipes etc. are required for infrastructural and other development purposes, others are required as industrial inputs.

The standard model assumes, for instance, that the United States can export as much as it wishes to African markets, given the stock of capital and labor and the various beneficial environmental factors in the United States, like the efficiency of capital and labor often cited in the literature. These trade statistics show that this is not exactly the case.

The United States' exports to Africa are limited by of demand constraints and other environmental factors, such as relative price differences in the US and African countries. Even when the stock of capital and labor has not changed, US exports to large African countries, such as Nigeria, Egypt, Ethiopia, Morocco, Kenya or South Africa, are constrained and even more so in the case of smaller countries, like Sierra Leone, the Republic of the Congo, GuineaBissau because of demand constraints. Recent experience shows that the United States cannot even export as much as it wishes to Japan. This is because any country's ability to export is not automatically followed by other counties' ability to import. The case in point is the 1997-98 dip in the US exports to the Asian markets. The decline in the US exports to the Asian markets was caused by the collapse of the region's financial system, which drastically reduced the region's ability to purchase US exports. During that period, the stock of capital and labor in the United States remained unchanged.

Between 1989 and 1992, the national economies of the major US trading partners in Africa, with the exception of Egypt, were experiencing a recession in real terms. Real GDP in Egypt was growing at an annual rate of 14.9 per cent 
from 1989 and 1992 and over 15 per cent between 1993 and 1996. Real GDP growth in Nigeria during the corresponding periods was 2.61 per cent and 0.7 per cent, respectively. The corresponding growth rates in Cote d'Ivoire were 2.58 per cent and 2.14 per cent respectively while, in South Africa they were 1.06 per cent in 1989-1992 and 2.36 per cent in 1993-1996. During these periods, all these countries experienced currency depreciation at the following annual rates: Nigeria at 17.55 per cent (1989-92), 1.12 per cent (1993-96); South Africa at 4.38 per cent (1989-92), 7.67 per cent (1993-96); Egypt at 12.67 per cent (1989-92), 12.34 per cent (1993-96) and Cote d'Ivoire at 1.21 per cent (1989-92) and 11.55 per cent (1993-96). A recession inhibits these countries' ability to export, while their weak currencies render imports expensive. It is obvious that such economic conditions can adversely affect not only the countries' ability to export but also their ability to purchase imports.

\section{INTERNATIONAL TRADE MODEL}

The US trade with Africa can be considered in two parts, namely the direction of trade and the volume of trade. The first part seeks to explain the source and destination of US trade, while the second part seeks to explain the volume of US trade with African countries. Statistics show that significant US trade with Africa between 1990-1996 was mostly between a few countries, see Department of Commerce (various years). US exports of manufactured products in excess of \$100 million went to Algeria, Angola, Egypt, Ghana, Morocco, Nigeria, South Africa and Tunisia. US exports of agriculture in excess of $\$ 100$ million during the same period went to Algeria, Egypt, Morocco, Nigeria, South Africa and Tunisia. US agricultural imports between 1990 and 1996 in excess of $\$ 100$ million came from Algeria and Cote d'Ivoire. On the other hand, US imports of manufactured products in excess of $\$ 100$ million were obtained from Egypt, Ghana Mauritius, Morocco, South Africa and Zaire (now the Democratic Republic of the Congo or DRC). The structure of some of these economies between 1980 and 1992 is given in Table 1. 
Table 1 Basic Indicators and Structure of the National Economy

\begin{tabular}{|c|c|c|c|c|c|c|c|c|c|c|c|c|c|}
\hline \multirow[t]{2}{*}{ Country } & \multirow{2}{*}{$\begin{array}{l}1997 \\
\text { Pop. } \\
\text { Mil- } \\
\text { lions }\end{array}$} & \multicolumn{2}{|c|}{$\begin{array}{l}\text { Per Capita } \\
\text { GDP }\end{array}$} & \multicolumn{2}{|c|}{$\begin{array}{c}\% \\
\text { Growth } \\
\text { rate }\end{array}$} & \multicolumn{2}{|c|}{$\%$ Agr. } & \multicolumn{2}{|c|}{$\begin{array}{c}\% \\
\text { Indus. }\end{array}$} & \multicolumn{2}{|c|}{$\begin{array}{c}\% \\
\text { Manuf. }\end{array}$} & \multicolumn{2}{|c|}{$\begin{array}{c}\% \\
\text { Serv. }\end{array}$} \\
\hline & & 92 & 497 & $\begin{array}{l}90- \\
690\end{array}$ & $\begin{array}{l}90- \\
97\end{array}$ & 65 & 97 & 65 & 97 & 65 & 97 & 65 & 97 \\
\hline & & & & 2.7 & 0.8 & & & 34 & & & & 51 & 3 \\
\hline $\mathrm{C}$ & & & 716 & 0.7 & 3.0 & 47 & 27 & 19 & 21 & 11 & 18 & 55 & 51 \\
\hline & & & & 5 & 4. & & & 27 & 32 & & 25 & 4. & 51 \\
\hline & & & & 2. & 4 & & & 14 & & & & 2 & 38 \\
\hline & & & 17 & 3.0 & 4.2 & 44 & 36 & 19 & 26 & 10 & 9 & 38 & 39 \\
\hline & & & & 4.2 & 2.1 & 35 & 39 & 18 & 16 & 11 & 16 & 47 & 5 \\
\hline & & & & 4.2 & 1.9 & & 15 & 28 & 33 & 16 & 33 & 49 & 5 \\
\hline & 1170 & & & 16 & 2.8 & & 33 & 13 & 47 & 6 & 47 & 33 & 21 \\
\hline & 40.6 & & 1939 & 1.2 & 1.5 & 10 & 5 & 42 & 39 & 23 & 24 & 48 & 57 \\
\hline Tun & 9.2 & & 950 & 3.3 & 4.3 & 22 & 13 & 24 & 29 & 9 & 19 & 54 & 58 \\
\hline USA & & & & 3.0 & 3.0 & & & 38 & 27 & 18 & 18 & 59 & 71 \\
\hline
\end{tabular}

Source: World Bank: World Development Indicators $(1990,1999)$

Based on 1992 and 1997 population, only four countries have a per capita GDP of over, or close to $\$ 1000$. This means that these four countries had the capacity to import from the US, not only highly essential imports such as transport equipment and food, items such as aircraft and associated equipment, civil engineering and contractors' plant and equipment, needed for the development of the local economy. The structure of many of these economies has undergone some changes between 1965 and 1997 and in many instances in such a way that per capita GDP actually declined from 1992 to 1997 . The structure of many of these economies shows a fairly stable share of services in the GDP but decline and improvements in the share of agriculture, industry and manufacturing appear in many cases. For instance, manufacturing declined in Algeria, Ethiopia and Ghana. The sector improved considerably in Côte d'Ivoire, Kenya, Morocco, Nigeria and Tunisia. Statistics show that none of Kenya, Nigeria, Ethiopia, Cote dilvoire and Ghana, all of which derive significant share of their GNP from agriculture is able to export up to 1 per cent of the United States agricultural needs. On the other hand Ghana, Mauritius and the Democratic Republic of the Congo which exported $\$ 100$ million or more of manufactured products to the United States during the 1980s, derive the lowest share of their GNP from manufacturing. It is hard to explain these apparent anomalies.

Where data is available, it is not entirely obvious how the structure of the national economies in Africa affects trade with the United States. Using the 
share of agriculture in the GNP, we can say that, in 1988, Algeria with a share of 13 per cent, Tunisia with a share of 14 per cent and South Africa with a share of 6 per cent were least dependent on agriculture among the African countries on which trade destination data are available. While Algeria exported no agricultural products to USA in 1992 , Tunisia exported $\$ 0.62$ per capita and South Africa exported $\$ 1.20$ per capita. On the other hand, Cote d'Tvoire, which derived 36 per cent of its GNP in 1988 from agriculture, exported over $\$ 11.00$ worth of agricultural products per capita in 1992 to the United States. Kenya with 31 per cent of its GNP from agriculture exported over $\$ 1.40$ per capita, compared to Nigeria with a share of 34 per cent which exported a mere $\$ 0.29$ of agricultural products per capita. However, when over $\$ 5,028$ million exports of mineral fuels, lubricants and related minerals are included, Nigeria's exports to USA rose to over $\$ 49.90$ per capita in 1992 . This means that Nigeria's trade expansion policy will have to emphasize the non-oil exports.

What role does demand play in Africa's trade with the United States? For this purpose, we consider income and population. To answer this question, we limit our analysis to countries with a population of at least 20 million and per capita GNP of at least $\$ 600$. Seven countries were selected on the basis of their size. Out of these, only three (or 42.8 per cent) bought combined imports of manufactured and agricultural products from the United States in 1990 in excess of $\$ 100$ million. Similarly, only three (or 30 per cent) of the ten countries which satisfied the minimum per capita GNP requirement bought combined imports of manufactured and agricultural products in excess of $\$ 100$ million in 1990. Out of four countries which satisfied both per capita GNP and population requirements, three countries (or 75 per cent) bought a combination of manufactured and agricultural products in excess of $\$ 1646$ million from the USA in 1990. In addition, 22 other high- and low-income countries for which data are available bought less than $\$ 100$ million worth of manufactured and agricultural products from the USA in 1992.

Five of the small, low-income countries bought at least $\$ 1.00$ manufactured and agricultural products per capita in 1992. Seven other small countries also bought at least \$1.00 of manufactured and agricultural products from the USA. Some of these countries, such as Namibia, Botswana and Mauritania depend more on the USA for their manufactures, while others, such as Mozambique rely equally on the USA for their imports of manufactures and agricultural products. This means that for the US corporations to be able to sell significant amounts of their exports in the African market, they will have to target large countries, especially high-income countries, such as Algeria, Botswana, Cameroon, Gabon, Mauritius, Senegal and South Africa and large countries such as Egypt. How much they can export to small high-income countries, such as Botswana, 
Cameroon, Cote d'Ivoire, Gabon, Mauritius, Senegal and Tunisia, or large lowincome countries, such as Kenya and Nigeria remains uncertain.

Other macroeconomic variables, which may be taken into consideration when evaluating the US trade with Africa, are domestic inflation and the strength of the local currencies. Many African countries are plagued by inflation while their currencies are generally overvalued. Five countries, including Nigeria, Mozambique and Guinea have devalued their currencies by over two or three hundred per cent, while Ghana and Uganda have devalued their currencies at least 1,000 per cent. Inflation reduces the purchasing power of the local currency and tends to increase the production cost of local industries. This means that local industries face higher unit cost and become non-competitive $v i s-\dot{a}-v i s$ their foreign competitors. At the same time, they have no incentive to produce because of inadequate domestic or foreign demand. Table 2 shows inflation and currency depreciation rates, between 1980 and 1990 (annual equivalent) for selected African countries, which normally trade with the United States. It shows that seven of these countries were plagued by hyperinflation between 1980 and 1990, the worst being Nigeria, Ghana, Tanzania, Mozambique, Zambia and Uganda, in order of severity. The countries with the highest rate of currency depreciation, also in order of severity are Nigeria, Tanzania, Mozambique, Zambia, Guinea, Uganda and Ghana. When exports of mineral fuels, lubricants and related mineral products are excluded, Nigeria, Tanzania and Uganda are among the countries with medium or large population with less than $\$ 1.00$ per capita trade with the United States during the 1980 s and 1990s.

Table 2 Inflation and Currency Depreciation Rate: Annual Equivalent $(1980-90)$

\begin{tabular}{|l|c|c|}
\hline \multicolumn{1}{|c|}{ Country } & Inflation Rate & $\begin{array}{c}\text { Rate of Currency } \\
\text { Depreciation }\end{array}$ \\
\hline Angola & - & 1.15 \\
\hline Botswana & 17.30 & 8.14 \\
\hline Cameroon & 12.32 & 2.66 \\
\hline Republic of Congo & 8.28 & 2.66 \\
\hline Cote d'Ivoire & 6.08 & 3.20 \\
\hline Egypt & 37.62 & 21.87 \\
\hline Ethiopia & 5.38 & 1.15 \\
\hline Ghana & 155.02 & $1,831.67$ \\
\hline Guinea & 71.52 & 801.16 \\
\hline Kenya & 20.58 & 25.47 \\
\hline
\end{tabular}


Table 2 continued

\begin{tabular}{|l|c|c|}
\hline Country & Inflation Rate & $\begin{array}{c}\text { Rate of Currency } \\
\text { Depreciation }\end{array}$ \\
\hline Morocco & 10.16 & 10.70 \\
\hline Mozambique & 170.60 & 343.56 \\
\hline Namibia & 23.67 & 28.35 \\
\hline Nigeria & 60.42 & 174.40 \\
\hline Senegal & 7.64 & 2.67 \\
\hline South Africa & 29.08 & 28.35 \\
\hline Tanzania & 116.58 & 258.03 \\
\hline Uganda & $7,132.86$ & $48,005.00$ \\
\hline Zambia & 406.67 & 584.00 \\
\hline Zimbabwe & 22.48 & 25.74 \\
\hline
\end{tabular}

Source: Calculated from IMF: Intemational Financial Statistics (1994)

Exchange rate misalignment is one of the causes of macroeconomic distortion for any economy. Overvalued currency stimulates imports for the countries concerned because imports are relatively cheaper, while weak currencies tend to stimulate exports because exports are relatively cheaper. Although the World Bank encourages prudent currency devaluation as a policy to discourage excessive imports and overdrawn reserves, reckless devaluation as in the case of Uganda, Ghana, Guinea, Zambia, Mozambique, Tanzania and, to some extent, Nigeria between 1980 and 1990 is very detrimental to the economy. It is beneficial to discourage excessive consumer importation. However, in many instances, African countries' imports have heavy development and industrial inputs contents. The more expensive these inputs are the costlier and more difficult it is to achieve meaningful development of basic infrastructure and industrialization.

A realistic trade model for Africa consider the changes in environmental factors demanded in the African Growth and Opportunity Act (AGOA), rapid increases in per capita income, exchange rate and labor productivity. Such a model must reflect the fact that low income, limited production capacity and exchange rate misalignment can reduce African countries' capacity to export to the US market. Two models are specified, respectively for the US imports and exports to selected African countries respectively. These are:

$$
\begin{aligned}
& \log \left(E_{\text {wu }}\right)=\alpha_{0}+\alpha_{1} \log \left(Y_{a}\right)+\alpha_{2} \log \left(L_{a}\right)+\alpha_{3} \log \left(e r_{a}\right) \quad \mu \\
& \log \left(E_{w a}\right)=\beta_{0}+\beta_{1} \log \left(Y_{v} / L_{v}\right)+\beta_{2} \log \left(Y_{a} / L_{a}\right)+\beta_{3} \log \left(e r_{a}\right)+v
\end{aligned}
$$


$E_{a u}$ represents the African country's export to USA and $E_{u a}$ represents US export to African country. $Y_{a}$ and $\mathrm{L}_{\mathrm{a}}$ represent the African country's GDP and population, respectively. The variables with subscript u refer to USA. Equation (1) assumes that any African country can export as much as it wishes to, provided it has the capacity to produce. However, equation (2) assumes that US exports to any African country may face demand constraints unless per capita income is high and the exchange rate is properly aligned. For meaningful trade to take place, $\alpha_{1}$ and $\beta_{2}$ are assumed to be positive and must be at least equal to unity. Where constraints exist the coefficients are numerically less than unity, $0<\alpha_{1}, \beta_{2}<1 . \alpha_{3}$ and $\beta_{3}$ may also be positive and numerically less than unity where demand or supply constraints exist. Where no such constraints exist, African countries will have the capacity to generate exports and adequate capacity to purchase US imports and therefore can use exchange rate policy to increase exports and reduce the flow of imports. The empirical results however show that, except for Nigeria (dominated by the country's petroleum export) and Senegal $\alpha_{1}$ is generally less than unity. And except for Congo, Ethiopia, Morocco, Nigeria and Senegal, $\beta_{2}$ is less than unity. The estimated constraint elasticity is shown in Table 3 . The results indicate that there are potential supply and demand constraints in the countries concerned.

Table 3 Elasticity of Trade Constraint with Respect to Income and the Exchange Rate

\begin{tabular}{|l|c|c|c|c|}
\hline & \multicolumn{2}{|c|}{ Export to USA } & \multicolumn{2}{c|}{ Import from USA } \\
\hline & $\alpha_{1}$ & $\alpha_{3}$ & $\beta_{2}$ & $\beta_{3}$ \\
\hline Botswana & 0.157 & 6.601 & 0.197 & 3.441 \\
\hline Cameroon & -0.354 & -2.222 & -0.222 & 2.992 \\
\hline Congo & -1.333 & 1.444 & 1.623 & -0.459 \\
\hline Cote d'Ivoire & -1.731 & 0.214 & -0.302 & 2.480 \\
\hline Egypt & -0.257 & 1.622 & 0.433 & 2.817 \\
\hline Ethiopia & 4.691 & 2.886 & 1.391 & 3.914 \\
\hline Ghana & 0.179 & 0.069 & 0.745 & -0.110 \\
\hline Morocco & 0.690 & -1.590 & 1.042 & 0.982 \\
\hline Nigeria & 1.114 & 1.279 & 1.732 & 0.218 \\
\hline Senegal & 2.724 & -2.593 & 7.323 & -5.882 \\
\hline South Africa & -0.408 & 2.292 & 0.791 & 2.780 \\
\hline Tanzania & 0.802 & 2.587 & -0.981 & 3.633 \\
\hline
\end{tabular}

Two public policy conclusions can be made on the basis of this study. Firstly, some of the countries considered in the study face severe supply constraints and others both supply and demand constraints. These constraints appear to be due to the low per capita GNP and low labor productivity. However some countries, 
like the Congo, Ethiopia, Nigeria and Senegal, for some inexplicable reasons appear to have a high propensity to import US goods even though they have low per capita GNP. Due to the perceived constraints, it does not appear that currency manipulation can be successfully used to stimulate export expansion or to reduce the flow of imports. In order for the United States to increase exports to the region, per capita income will have to be considerably increased. Excessive trade liberalization policy in Africa may be more harmful to the African economy and in turn jeopardize the US export promotion policy. Excessive external imbalance may be as harmful to the African economy as it may be to the American export sector. If the US wishes to export more to the African market, it will surely be in the US's interest to promote policies to enhance income growth in Africa. Such policies include debt relief, direct foreign investment and technology transfer. Similarly, African countries wishing to export must adopt a wide range of internal policies to boost domestic production by accelerating the rate of capital formation, increase efficiency and labor productivity and avoid overvalued currency. They must also be aware that the rampant and widespread corruption and the lack of transparent governance discourage direct private investment and genuine technology transfer and thereby militate against real income growth. Statistics show that many African countries are plagued by inflation, which reduces the purchasing power of the local currency. Policies to stimulate domestic output will have to include policies to control inflation, enhance efficiency and stabilize currency value.

\section{SUGGESTED DIRECTION FOR US TRADE AND INVESTMENT IN AFRICA IN THE $21^{\text {ST }}$ CENTURY AND BEYOND}

The data we have reviewed show that total US exports of manufactured products to Africa in 1990 was \$5 589 million, \$1 569 million of which was shipped to South Africa and $\$ 7.133$ million in $1996, \$ 707$ million of which was shipped to Egypt. US exports of agricultural products in 1990 were \$1 857 million and \$2 712 million in 1996.

On the other hand, US imports of manufactured products totaled a mere $\$ 2464$ million in 1990 and $\$ 3338$ million in 1996, while imports of agricultural products were $\$ 645$ million and $\$ 903$ million in 1990 and 1996 respectively.

Table 4 throws more light on the growth and pattern of US trade with selected African countries, which have bought at least $\$ 100$ million per annum of a combination of manufactured and agricultural products from the United States between 1990 and 1996. Based on 1990 level of trade, Algerian and Nigerian exports to the US fell in 1996 and imports from Algeria and Morocco also fell. The Table also shows that Egypt and South Africa play the most significant role 
in the US trade with Africa. Although the United States corporations export almost as much to Egypt in per capita terms as they export to South Africa, US corporations import only a paltry $\$ 3.84$ per capita from Egypt in combined manufactures and agricultural products. The lob-sided US trade with South Africa is accounted for, in part by per capita GDP in South Africa and the US investments in South Africa.

Table 4 Growth and Per Capita Distribution of US Trade to Africa 1990-96

\begin{tabular}{|l|c|c|c|c|c|c|c|}
\hline Country & $\begin{array}{c}\text { 1992 } \\
\text { Pop } \\
\text { (Million) }\end{array}$ & $\begin{array}{c}\text { Total } \\
\text { Import } \\
\text { (SM) }\end{array}$ & $\begin{array}{c}\text { Per } \\
\text { Capita } \\
\text { Import } \\
\text { S }\end{array}$ & $\begin{array}{l}\text { Total } \\
\text { Export } \\
\text { (SM) }\end{array}$ & $\begin{array}{c}\text { Per } \\
\text { Capita } \\
\text { Export } \\
\text { S }\end{array}$ & \multicolumn{2}{|c|}{$\begin{array}{c}\text { Growth in Trade } \\
\text { 90-96 }\end{array}$} \\
\cline { 6 - 9 } & Import & $\begin{array}{c}\text { Export } \\
\text { (SM) }\end{array}$ \\
\hline Algeria & 26.3 & 1 & .04 & 626 & 23.80 & -500 & -326 \\
\hline $\begin{array}{l}\text { Côte } \\
\text { d'Ivoire }\end{array}$ & 12.9 & 165 & 12.79 & 83 & 6.43 & 197 & 62 \\
\hline Egypt & 54.7 & 210 & 3.84 & 2,964 & 54.19 & 283 & 904 \\
\hline Morocco & 26.2 & 108 & 4.12 & 433 & 11.96 & 130 & -19 \\
\hline Nigeria & 101.9 & 46 & 0.45 & 982 & 9.64 & -52 & 265 \\
\hline $\begin{array}{l}\text { South } \\
\text { Africa }\end{array}$ & 39.8 & 1,468 & 36.88 & 2,329 & 58.52 & 611 & 1380 \\
\hline Tunisia & 8.4 & 29 & 3.45 & 165 & 19.64 & 36 & 12 \\
\hline Average & - & - & 12.22 & - & 26.31 & & \\
\hline USA & 255.4 & 2,975 & 11.65 & 9,369 & 36.68 & & \\
\hline
\end{tabular}

Source: US Department of Commerce, 1996

During 1992, the United States imported about $\$ 12.00$ worth of manufactured and agricultural products from and exported approximately $\$ 26.00$ worth of manufactured and agricultural products per capita to Africa. On the other hand, the distribution of African trade with the USA ranges from a low $\$ .04$ of exports per capita from Algeria to $\$ 36.88$ per capita from South Africa. In 1992, the USA exported the least in manufactured and agricultural products to Cote d'Ivoire. That year USA exported $\$ 6.43$ per capita to Cote d'Ivoire and $\$ 9.64$ per capita to Nigeria. Most US exports went to South Africa, about $\$ 58.52$ per capita, followed by Egypt with $\$ 54.19$ per capita. Leaving out Algeria and Nigeria, this means that the United States imported $\$ 12.22$ per capita worth of manufactured and agricultural products from every African man, woman and child in 1992 and sold approximately $\$ 26.31$ per capita worth of manufactured and agricultural products during that year.

In the past, the United States corporations have tied their direct investment in Africa to their raw material needs. The African Growth and Opportunity Act 
passed by the US Congress and signed into law on May 18, 2000 encouraged African political leaders to hope that there is an intention to broaden the scope of US trade and investment in Africa. Although there is considerable controversy over the true intents, the Act has ostensibly emphasized the need for structural reforms and the eradication of corruption as means of attracting direct foreign investments to Africa. American corporations should therefore be encouraged to conduct their trade in such a way as to serve not only the needs of their manufacturing industries, but also to help African-based corporations to effectively use and expand their production potential. In fact, the US government can adopt policies that could encourage US corporations to invest in sectors where available resources show that the benefits of comparative advantage could be exploited. Using the per capita imports and exports in Table 4 as a planning target for the next ten years, the major US corporations could assist their trading partners in Africa to raise their combined exports of manufacturers and agricultural products to between $\$ 12.22$ and $\$ 26.31$ per capita. In turn such countries would be able to purchase at least $\$ 26.31$ per capita worth of manufactured products from the USA, including industrial raw materials and inputs for infrastructural development and agricultural products. International trade theory asserts that by enhancing income growth in the importing country, the exporting country can in turn hope to export even more. If there is a will, the United States corporations have the technology and the resources to invest in selected sectors in Africa, to promote their interest and also expand the manufacturing base and enhance income growth in Africa. They should not limit their investment interest to the mining and petroleum sectors, but invest in all other sectors where comparative advantage exists and new technologies can be acquired.

Trade expansion by African countries is not the responsibility of the United States alone. The United States companies have shown interest in importing agricultural products such as cocoa, coffee and sugar from Africa. Although the US demand for Nigerian cocoa has been declining over the years, the US demand for natural nubber has been increasing. American companies have also shown interest in buying cotton fabrics, furniture and spices from Egypt and a broad range of manufactured products from South Africa. African countries should do more rather than less in encouraging US corporations to buy their exports by ensuring that they remain competitive in product quality and pricing.

With regard to foreign direct investment, African governments must do more to render their countries more attractive for foreign investment if they wish to encourage American companies to invest in their countries. They must do more to eradicate corruption and revamp their inefficient social infrastructures that render many African countries risky and the cost of business too high. Rather than being indecisive about the true intent of multinational corporations, they 
must realize that the ultimate conducts of the multinational corporations are dictated and encouraged by the conduct of the citizens and businesses in Africa. Where the laws are enforced, the multinational corporations will obey them. Therefore these corporations should be invited to invest in such sectors as power generating plants and communications network and other key sectors, a means of reducing the bottlenecks in every sector of the economy. They must also do more to liberalize their economies and remove artificial subsidies that make it difficult to determine the true costs of doing business.

\section{REFERENCES}

1 AMUEDO-DORANTES, C. \& POZO, S. (1997) "Exchange Rate Volatility and Economic Growth" (Paper presented at the Midwest Economics Association Annual Meeting: Kansas City, March.

2 ASHEGHIAN, P. \& SAIDI, R. (1993) "Real Exchange Rate Variability and LDCs Exports" (Unpublished).

3 EATON, J. \& GERSOVITZ, M. (1980) "LDC Participation in Reply to: International Financial Markets, Debt and Reserves", Journal of Development Economics, 7: 3-21.

4 ESFAHANI, H.S. (1991) "Exports, Imports and Economic Growth in Semi-Industrialized Countries", Journal of Development Economics, 35: 93-116.

5 FEDER, G. (1982) "On Exports and Economic Growth", Journal of Development Economics, 12: 59-73.

6 GYIMAH-BREMPONG, K. (1991) "Export Instability and Economic Growth in Sub-Saharan Africa", Economic Development and Cultural Change, 39(4).

7 JIANG, R. (1997) "Export Structures and Economic Growth" (Unpublished).

8 LONDON, E. (1997) "Trade Liberalization with a Fixed Exchange Rate", The International Trade Journal, XI, No 2, Summer.

9 MATHESON, D.J. (1989) "Exchange Rate Arrangements and Monetary Policy", Finance \& Development, March.

10 ONAFOWORA, O.A. \& OWOYE, O. (1998) "Trade Liberalization and Economic Growth Nexus: Issues and Evidence for Sub-Sahara Africa" Unpublished.

11 RANA, P.B. (1988) "Exports, Policy Changes and Economic Growth in Developing Countries after the 1973 Oil Shock", Journal of Development Economics, 28: 261-264.

12 SHEEHEY, E. (1990) "Export and Growth: A Flawed Framework", Journal of Development Economics, 27(1). 
13 TYLER, G. (1981) "Growth and Export Expansion in Developing Countries: Some Empirical Evidence", Journal of Development Economics, $9(1)$.

14 US DEPARTMENT OF COMMERCE, International Trade Administration (Various Years), U.S. Foreign Trade Highlights.

15 US DEPARTMENT OF COMMERCE (1998) "US Direct Investment in Africa", On line: www.sadc-usa.net/trade/ustrade/direct 96 html.

16 (1998) "Get the Facts", On line:

www.usafica.org/fact/ustrade.html

17 US Trade Task Force (1997) "US Must Not Marginalize Trade/Investment with Africa" http://www.usisisrael.org.il/publish/press/trade.archive.html. 